\title{
The many faces of earnings before interest, tax, depreciation and amortisation (EBITDA): Assessing the decision usefulness of EBITDA disclosure by Johannesburg Stock Exchange-listed companies
}

\begin{tabular}{|c|c|}
\hline \multicolumn{2}{|c|}{$\begin{array}{l}\text { Authors: } \\
\text { Mattheus T. Mey }{ }^{1} \text { (I) } \\
\text { Christiaan Lamprecht }^{1} \text { (D) }\end{array}$} \\
\hline \multicolumn{2}{|c|}{$\begin{array}{l}\text { Affiliations: } \\
{ }^{1} \text { School of Accountancy, } \\
\text { Faculty of Economic and } \\
\text { Management Sciences, } \\
\text { Stellenbosch University, } \\
\text { Cape Town, South Africa }\end{array}$} \\
\hline \multicolumn{2}{|c|}{$\begin{array}{l}\text { Corresponding author: } \\
\text { Mattheus Mey, } \\
\text { tmey@sun.ac.za }\end{array}$} \\
\hline \multicolumn{2}{|c|}{$\begin{array}{l}\text { Dates: } \\
\text { Received: } 20 \text { June } 2019 \\
\text { Accepted: } 15 \text { May } 2020 \\
\text { Published: } 09 \text { July } 2020\end{array}$} \\
\hline \multicolumn{2}{|c|}{$\begin{array}{l}\text { How to cite this article: } \\
\text { Mey, M.T. \& Lamprecht, C., } \\
\text { 2020, 'The many faces of } \\
\text { earnings before interest, } \\
\text { tax, depreciation and } \\
\text { amortisation (EBITDA): } \\
\text { Assessing the decision } \\
\text { usefulness of EBITDA } \\
\text { disclosure by Johannesburg } \\
\text { Stock Exchange-listed } \\
\text { companies', Journal of } \\
\text { Economic and Financial } \\
\text { Sciences 13(1), a488. } \\
\text { https://doi.org/10.4102/jef. } \\
\text { v13i1.488 }\end{array}$} \\
\hline \multicolumn{2}{|c|}{$\begin{array}{l}\text { Copyright: } \\
\text { (c) 2020. The Authors. } \\
\text { Licensee: AOSIS. This } \\
\text { is licensed under the } \\
\text { Creative Commons } \\
\text { Attribution License. }\end{array}$} \\
\hline \multicolumn{2}{|l|}{ Read online: } \\
\hline 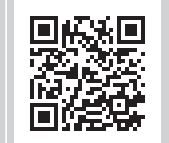 & $\begin{array}{l}\text { Scan this QR } \\
\text { code with your } \\
\text { smart phone or } \\
\text { mobile device } \\
\text { to read online. }\end{array}$ \\
\hline
\end{tabular}

Orientation: The voluntary disclosure of non-Generally Accepted Accounting Principles (non-GAAP) earnings may lack decision-usefulness if not faithfully represented or comparable. Commonly accepted as being well defined, earnings before interest, tax, depreciation and amortisation (EBITDA) may be misleading if labelled, defined and calculated inconsistently.

Research purpose: To assess the decision-usefulness of EBITDA disclosure by Johannesburg Stock Exchange (JSE)-listed companies.

Motivation for the study: Prior research on voluntary disclosure largely excluded EBITDA from its focus, accepting it as standardised.

Research approach/design and method: A quantitative content analysis was used to analyse the EBITDA disclosure in 220 Stock Exchange News Service (SENS) reports in which JSE-listed companies reported their annual results for the period 2014-2016.

Main findings: Companies inconsistently labelled, defined and calculated EBITDA. Twentyfour per cent of the SENS reports labelled and defined EBITDA as earnings before interest, tax, depreciation and amortisation, but calculated it by adjusting for other items as well. Companies' definitions of EBITDA also differed widely, with 27 different definitions identified in 52 SENS reports that disclosed an unmodified EBITDA label.

Practical/managerial implications: Existing JSE reporting requirements appear lacking in ensuring that companies disclose EBITDA that is faithfully represented and comparable. The identified diversity of definitions has implications where EBITDA is used for valuation and contracting purposes.

Contribution/value-add: The study contributes to the voluntary disclosure literature by focussing on a non-GAAP earnings measure that has largely been ignored by prior research, namely EBITDA. Empirical evidence is presented on the diversity that exists in EBITDA disclosure by JSE-listed companies.

Keywords: EBITDA; non-GAAP; decision useful; comparability; faithful representation; inconsistency.

\section{Introduction}

Earnings before interest, tax, depreciation and amortisation (EBITDA), widely perceived as accounting EBITDA (Brown 2016; International Accounting Standards Board [IASB] 2017a), is an important non-GAAP earnings measure (Papa, Peters \& Schacht 2016). Non-GAAP earnings, although not defined in accounting standards, is seen by financial executives and investors as an important disclosure tool that enables management to provide users of financial reports with proprietary information that, arguably, provide better decision-useful information than GAAP earnings (Graham, Harvey \& Rajgopal 2005; Papa et al. 2016). Generally Accepted Accounting Principles (GAAP) earnings encompass any earnings measure that is defined in accounting standards.

The importance of non-GAAP earnings to users of financial reports is underscored by the assumption that, even in efficient markets, company management has superior inside information that can be decision-useful to users (Healy \& Palepu 2001). However, because non-GAAP earnings are not defined in accounting standards, management decides how to label, define and calculate 
non-GAAP earnings. This discretion could result in inconsistencies between how companies calculate nonGAAP earnings, raising the concern of a lack of comparability (IASB 2017a). A further concern is that if non-GAAP earnings are inaccurately labelled and inadequately explained, it may not be faithfully represented, but misleading (IASB 2017a).

Recent evidence from European institutional investors showed that professional investors, in predicting the future cash flows of companies, perceive EBITDA as being more relevant and a more faithful representation than bottom-line GAAP earnings (Cascino et al. 2016). In addition, anecdotal evidence suggests that, for valuation purposes, EBITDA is widely used in South Africa (Hattingh 2012). Contrary to the perception of its standardised format, evidence exists suggesting that companies are not consistent on how they calculate EBITDA (Hitz 2010; IASB 2016). Inconsistencies in the presentation and calculation of EBITDA are possible because it is not comprehensively defined in accounting standards, nor does explicit disclosure requirements exist. Leaving the quality of disclosure up to the discretion of management may result in EBITDA information that is not decision-useful.

The research question this study attempts to answer is whether EBITDA disclosure by companies listed on the Johannesburg Stock Exchange (JSE) is decision-useful to the users of financial statements. To answer the research question, two concepts underlying decision-usefulness of financial information, namely faithful representation and comparability (IASB 2018), were assessed. A faithful representation requires a complete depiction of all the information necessary to understand a particular economic phenomenon (IASB 2018). Moreover, a faithful representation will also enable a degree of comparability as sufficient information is provided to enable users to make comparisons (IASB 2018). While companies label, define and calculate EBITDA in an inconsistent manner, without providing complete disclosure necessary to understand the inconsistencies, the resultant information may not be decision-useful (IASB 2017a; PWC 2014). In this sense, consistency also refers to the congruency between the EBITDA label, definition and calculation.

Three research objectives were set to address the research question. The first research objective was to describe how companies labelled EBITDA when discussing their annual performance. This objective intends to assess whether only the expected adjustment to earnings was made, or if any other adjustment were made. For example, a company could present an unmodified EBITDA label, thereby suggesting it to be a standardised measure that only adjusted International Financial Reporting Standards (IFRS) earnings with interest, tax, depreciation and amortisation (ITDA-adjustments). Alternatively, a company could present a modified EBITDA label (e.g. 'adjusted EBITDA') that indicated that EBITDA was also calculated by adjusting for other items.

The second research objective was to identify how companies defined EBITDA. This objective was necessary to determine the extent to which EBITDA was comparable between companies and to assess whether the definition was consistent with the EBITDA label. For example, if a company discloses an unmodified EBITDA label, but defines it as adjusting for items other than ITDA-adjustments, the label may be seen as not faithfully representing its measurement. In contrast, a modified EBITDA label that includes an indication of further adjustment, for example, 'adjusted EBITDA', may be seen as a faithful representation as users would be informed not to assume that the measure only excludes ITDA-adjustments.

The third and last research objective was to recalculate EBITDA based on the definition provided in order to assess whether the adjustments made in calculating EBITDA agreed to the definition provided. SENS reports that disclosemodified EBITDA labels already exhibit a measure of faithful representation by indicating that adjustments other than those implied by the accepted definition of EBITDA can be expected. In contrast, SENS reports with unmodified EBITDA labels may be more at risk of a lack of faithful representation if inconsistencies exist between the label, definition and calculation. In particular, where SENS reports disclose an unmodified label and either provides the standard definition or no definition, users may be inclined to assume an EBITDA calculation that adjusts for ITDA-adjustments only. Therefore, only SENS reports that disclosed an unmodified label were included in this objective.

\section{Literature review}

\section{Decision-usefulness of earnings before interest, tax, depreciation and amortisation - Faithful representation and comparability}

The disclosure of non-GAAP earnings, as an alternative representation of a company's performance, is widely used in financial reports. Evidence of the extent of non-GAAP earnings disclosure in press releases has been provided for companies in the USA (Bhattacharya et al. 2004), Canada (Entwistle, Feltham \& Mbagwu 2005) and Europe (Aubert \& Grudnitski 2014). The disclosure of non-GAAP earnings in annual reports has also seen an increase in New Zealand (Rainsbury, Hart \& Buranavityawut 2015), Australia (Cameron 2012) and South Africa (Howard, Maroun \& Garnett 2019).

From a normative theoretical perspective provided by the Conceptual Framework for Financial Reporting of the IASB, a vital characteristic necessary for non-GAAP earnings to be a faithful representation is for companies to provide complete information about the non-GAAP performance measure that will enable users to better understand the measure and prevent them being misled (IASB 2018). Providing complete information will also facilitate comparability (IASB 2018), as users will be able to determine how different companies calculate non-GAAP earnings. While most non-GAAP earnings measures already convey to the users a warning of non-standardised compilation, seemingly standardised non-GAAP earnings measures, such as EBITDA, may be more risk of not being faithfully 
represented if inaccurately labelled or inconsistently calculated.

Earnings before interest, tax, depreciation and amortisation is, because of its seemingly defined nature, more likely to be susceptible to biased disclosure, because management can make adjustments other than ITDA-adjustments and still label the measure so calculated as EBITDA. Recognising the risk of misuse, analysts have raised their concerns that reported EBITDA may be misleading because the adjustments that companies make are inconsistent between companies (IASB 2017a; Papa et al. 2016). Therefore, in the absence of proper disclosure, if the calculation includes adjustments other than ITDA-adjustments, then EBITDA will not be faithfully represented.

\section{Earnings before interest, tax, depreciation and amortisation in voluntary disclosure literature}

According to Verriest, Bouwens and De Kok (2019), EBITDA has largely been excluded from the scope of voluntary disclosure research. A possible reason for the exclusion from prior studies is the perception of EBITDA as a defined measure (e.g. Allee et al. 2007; Entwistle, Feltham \& Mbagwu 2010). In their questionnaire to 81 professional investors from 16 countries, Cascino et al. (2016) referred to EBITDA in its standardised format, suggesting that investment professionals also view EBITDA as a defined measure. Earnings before interest, tax, depreciation and amortisation is also discussed in various tertiary textbooks as a standardised measure that only adjusts for interest, tax, depreciation and amortisation (O’Regan 2006; Walton 2000; White, Sondhi \& Fried 2003).

Studies that have focussed on the prevalence and informativeness of EBITDA include D'Souza, Ramesh and Shen (2010), Rozenbaum (2019) and Verriest et al. (2019). D'Souza et al. (2010) investigated press releases of US companies over the period 2000-2003 and found that companies where depreciation and interests costs tended to be more prevalent were more inclined to disclose more information about the line items that make up EBITDA (i.e. ITDA-adjustments). They interpreted this finding as being consistent with the management of those companies wanting to place focus on EBITDA as a more comparable measure than bottom-line earnings (D'Souza et al. 2010). Pointing out the risk of overreliance on EBITDA, Rozenbaum (2019) found evidence in US companies' earnings announcements from 2003 to 2011 that management who fixate on EBITDA, vis-à-vis GAAP earnings, when making investment and lending decisions over-invest in capital and over-lever their firms. In addition, management was more inclined to disclose EBITDA where it was linked to executive compensation contracts (Rozenbaum 2019). Verriest et al. (2019) extended the abovementioned line of inquiry and investigated the prevalence and validity of EBITDA reporting in the 22354 annual reports and 57911 press releases of US companies over the period 20052016. They found that $25 \%$ of annual reports and $18 \%$ of press releases disclosed EBITDA, but found no evidence that companies were opportunistic when reporting EBITDA.
Furthermore, they found that EBITDA was less able to predict profitability than GAAP earnings. All three of these EBITDAfocussed studies assumed EBITDA to be standardised, consisting of ITDA-adjustments only. Whether inconsistencies existed between how companies labelled, defined and calculated EBITDA were not investigated nor considered.

A limited number of studies provide evidence of inconsistent EBITDA disclosure. Isidro and Marques (2013) investigated non-GAAP earnings disclosed in press releases of the top 500 European-listed firms for the year 2005 and identified only four (of the 500) instances where disclosed EBIT and EBITDA were not compiled from the respective adjustments for interest, tax, depreciation and amortisation. In the Australian-based study, Cameron (2012) investigated the prominence of nonGAAP earnings in the annual reports of the top 50 Australianlisted companies from 2007 to 2009. Cameron (2012) identified modified variants of EBIT and EBITDA (e.g. underlying EBITDA) made up the majority of non-GAAP earnings reported in the narrative sections of the annual reports. Although Cameron (2012) found inconsistencies in the types of adjustments made in deriving at the modified EBITDA, no details of the types of inconsistencies nor details of any discrepancies between how companies labelled EBITDA and defined EBITDA were provided. South African evidence on the extent and nature of EBITDA disclosure in financial reports is lacking. In assessing potential opportunistic use of nonGAAP earnings in the annual reports of JSE-listed companies from 2010 to 2014, Howard et al. (2019) included 'EBIT' as a search term, but did not provide any evidence on the nature or extent of EBITDA reporting by South African companies.

\section{Disclosure transparency and its effect on different types of users}

The way in which non-GAAP earnings measures are presented may influence users' perceptions about a company's performance. In particular, less-sophisticated users may be more susceptible to mispricing company shares if they are unable to understand whether the information is reliable and accurately presented (Young 2014). As argued by Johnson and Schwartz (2005), if users of financial reports fixate on earnings figures displayed more prominently and ignore other relevant information disclosed elsewhere in a financial report, those users may make decisions based on incomplete information. Similarly, if users of financial reports fixate on the EBITDA label by which management refers to EBITDA when discussing company performance, users may ignore the information contained elsewhere in the financial report that indicates that EBITDA was modified for items other than ITDA-adjustments. However, if an EBITDA label indicates that EBITDA has been modified, users would be prompted to inspect the financial report further to determine the types of adjustments made.

In support of the above-mentioned argument, Elliott (2006) provided experimental evidence, suggesting that lesssophisticated investors tend to fixate on more prominently disclosed non-GAAP earnings. A solution to the problem of fixation by less-sophisticated users may be to increase 
disclosure transparency by providing complete information (Young 2014). While EBITDA is used in modified format (i.e. where items other than ITDA-adjustments are adjusted for), the label should then reflect that adjustments were made and the financial report should include a definition of how the measure was compiled. Doing so will provide complete information as envisaged by the IASB's Conceptual Framework for Financial Reporting, thereby facilitating a faithful representation of the measure.

\section{Disclosure requirements of the Johannesburg Stock Exchange}

As a capital market regulator in South Africa, a key responsibility of the JSE is to ensure that high-quality financial reporting is maintained by JSE-listed companies. With the exception of headline earnings and pro-forma information, the JSE has no explicit disclosure requirements pertaining to the disclosure of non-GAAP earnings in SENS reports (Johannesburg Stock Exchange Limited [JSE] 2017) (Authors' comment: While documenting the results of this study, the JSE issued, for public comment, a proposed revision to its non-GAAP earnings disclosure requirements; JSE 2019). Therefore, when companies report their annual results through SENS and include other non-GAAP earnings in the report, the SENS report needs only to meet the general disclosure requirements of the JSE. Those requirements are that the SENS report is prepared in accordance with the IASB's concepts underlying decision-useful information, as stipulated in the Conceptual Framework for Financial Reporting and the presentation and disclosure requirements of International Accounting Standard 34 Interim Financial Statements (IAS 34) (JSE 2017). The conceptual framework, however, is concepts-based and does not provide explicit disclosure requirements (IASB 2018). This lack of explicitness leaves management with discretion in how to report non-GAAP earnings. International Accounting Standard 34 too is silent on specific disclosure requirements in instances where companies disclose non-GAAP earnings as a sub-total in, or adjacent to, the income statement (IASB 2017b), which in the case of SENS reports means that management can use discretion in how EBITDA is labelled, defined and calculated. In contrast, reporting requirements already set by international regulators, for example, the United States Securities and Exchange Commission (SEC), are explicit in how non-GAAP earnings should be labelled, defined and calculated (Securities and Exchange Commission [SEC] 2003, 2018).

In the light of increased reporting costs associated with more transparent reporting and the risk of information overload from too much disclosure (Young 2014), an important consideration for the JSE should be whether its existing reporting requirements are adequate in ensuring that companies disclose EBITDA that is decision-useful.

\section{Research design}

\section{Research approach and strategy}

A quantitative content analysis was used to analyse the EBITDA disclosure in the SENS reports of JSE-listed companies. Content analysis is a research method used to describe the content of communication in an objective and systematic manner and is a method often used in analysing text (Beattie 2014; Bryman 2012). Although content analysis can also be used to investigate the meaning conveyed by a particular content (referred to as the latent content), this study focussed on describing the manner in which companies labelled, defined and calculated EBITDA. The content of EBITDA labels and definitions included in SENS reports enabled an analysis of the extent to which the information lacked faithful representation and comparability.

The unit of analysis in this study was the SENS reports of JSE-listed companies in which EBITDA was disclosed as a measure of financial performance for the financial years ending in 2014-2016. The period was selected to allow for a sufficient number of observations and to provide evidence of recent disclosure practices by South-Africanlisted companies.

\section{Data collection}

The data were collected by first considering the population. The population in this study included all SENS reports that met the search criteria of disclosing EBITDA as a measure of companies' annual performance. By focussing on the total population of companies that disclosed EBITDA, sampling errors were eliminated. Initially, a list of all JSE-listed equities was obtained. Duplicate entries (where companies appeared more than once because of more than one type of listed equity), as well as entries where the respective companies listed outside the period used in the study, were removed. Table 1 presents the population of SENS reports containing valid instances of EBITDA as a performance measure, as compiled from the initial list of 440 listed equities on the IRESS database.

Following the example of Malone, Tarca and Wee (2016), the search functionality in Adobe Acrobat was used to search across the PDFs of the final population of SENS reports for the search term 'EBITDA'. This narrow search term could have resulted in the exclusion of SENS reports that did not use the acronym 'EBITDA', but instead, use a narrative depiction, namely 'earnings before interest, tax, depreciation and amortisation'. However, as shown earlier, the literature indicates that companies commonly use the acronym 'EBITDA' when referring to 'earnings before interest, tax, depreciation and amortisation' and the use of the narrower search term reduced subjectivity in the use of other search terms.

Of the 329 SENS reports in the initial selection, a total of 307 SENS reports disclosed EBITDA. As the focus of the study was on instances where EBITDA was disclosed as a measure of company performance, the next step was to identify the SENS reports in which EBITDA was presented as a measure of annual performance. This step was necessary as some companies disclosed EBITDA not as a measure of 
TABLE 1: Determining the population of SENS reports containing earnings before interest, tax, depreciation and amortisation as a performance measure. Population selection process Companies Company-years (SENS reports)

Initial identification of JSE-listed companies on IRESS database

Total number of JSE-listed equities on the IRESS database at time of data collection.

440

(66)

removing duplicate selections.

Sub-total

Remaining number of companies whose SENS reports for the period 2014-2016 were downloaded in PDF format from the IRESS database and searched for the disclosure of EBITDA.

Determining the population

Identification of SENS reports in which the 329 companies identified above disclosed EBITDA.

SENS reports in which EBITDA was disclosed for any of the financial years ending in 2014, 2015 and 2016.

EBITDA, earnings before interest, tax, depreciation and amortisation; JSE, Johannesburg Stock Exchange; SENS, Stock Exchange News Service.

TABLE 2: Research objectives linked to the data recording process and data analysis.

\begin{tabular}{lll}
\hline Research objective (RO) & Data recording \\
\hline RO 1 & Describe how EBITDA was labelled. & Document how SENS reports labelled EBITDA. \\
RO 2 & $\begin{array}{l}\text { Identify how EBITDA was defined and assess } \\
\text { whether the definition is consistent with the label. }\end{array}$ & $\begin{array}{l}\text { Document how SENS reports defined EBITDA. } \\
\text { Document list of all definitions. } \\
\text { Document instances where definitions were inconsistent } \\
\text { with labels. }\end{array}$ \\
RO 3 & $\begin{array}{l}\text { Recalculate EBITDA based on the definition and } \\
\text { assess whether the calculation is consistent with } \\
\text { definition }\end{array}$ & $\begin{array}{l}\text { Document instances where the recalculated EBITDA } \\
\text { differs from the reported EBITDA }\end{array}$
\end{tabular}

EBITDA, earnings before interest, tax, depreciation and amortisation; SENS, Stock Exchange News Service.

performance, but for other purposes. For example, some companies disclosed EBITDA as an input used in determining the fair value of items.

Of the initial population of 307, 87 company-year observations, where EBITDA was disclosed in a SENS report but not as a measure of performance, were excluded. After excluding the 87 company-year observations, the final population of 220 company-year observations, relating to 86 companies, remained. The number of companies was 71 in 2014, 72 in 2015 and 77 in 2016. With the exception of the oil and gas industry and the utilities industry, the population of 220 SENS reports included all the JSE industries. No single industry appeared over-represented. The highest concentration of EBITDA reporters was found in the following industries, making up $81 \%$ of the total population: industrials $(30 \%)$, basic materials $(28 \%)$, consumer services (14\%) and technology (9\%).

Once the population was determined, the SENS reports of those companies were systematically analysed and the relevant data recorded in line with the stated research objectives of the study. Table 2 presents a summary that links the research objectives with the data recording process that was followed. The table also indicates the techniques used to analyse the data. Table 2 is followed by an explanation of the data recording process with illustrative examples.

\section{Research objective 1}

To achieve the first research objective of determining how companies labelled EBITDA in their SENS reports, the first occurrence of an EBITDA label, whether modified or unmodified, was documented for each of the 220 SENS reports. Figure 1 depicts an extract from RCL Foods Limited's 2016 SENS report to illustrate an instance where an unmodified EBITDA label was disclosed.

In contrast to the disclosure of an unmodified EBITDA label in Figure 1, Figure 2 provides an example of a modified EBITDA label, as disclosed in the 2016 SENS report of Adcorp Holdings Limited. Figure 2 shows that EBITDA was labelled as 'normalised EBITDA', which suggests that EBITDA was not calculated by adjusting for ITDA-adjustments only.

\section{Research objective 2}

Research objective 2 was to identify how EBITDA was defined in the 220 SENS reports. Through the use of the search terms 'EBITDA', 'EBIT', 'earnings before' and 'before', the entire SENS report was searched to identify any instance where a definition of EBITDA was provided. The additional search terms were deemed necessary for in case a SENS report disclosed an unmodified EBITDA label (which would have resulted in being selected when performing the first research objective), but then disclosed a narrative definition of 'earnings before...' without referring to the term EBITDA again. Therefore, although the search term 'EBITDA' might have sufficed, in order to obtain assurance about the completeness of the search, the other search terms were also used when the term 'EBITDA' did not lead to the discovery of a definition.

Figure 3 provides an example of how EBITDA was defined in the 2016 SENS report of RCL Foods Limited. Appearing in the income statement, EBITDA was defined as 'Operating profit before depreciation, amortisation and impairment'. 


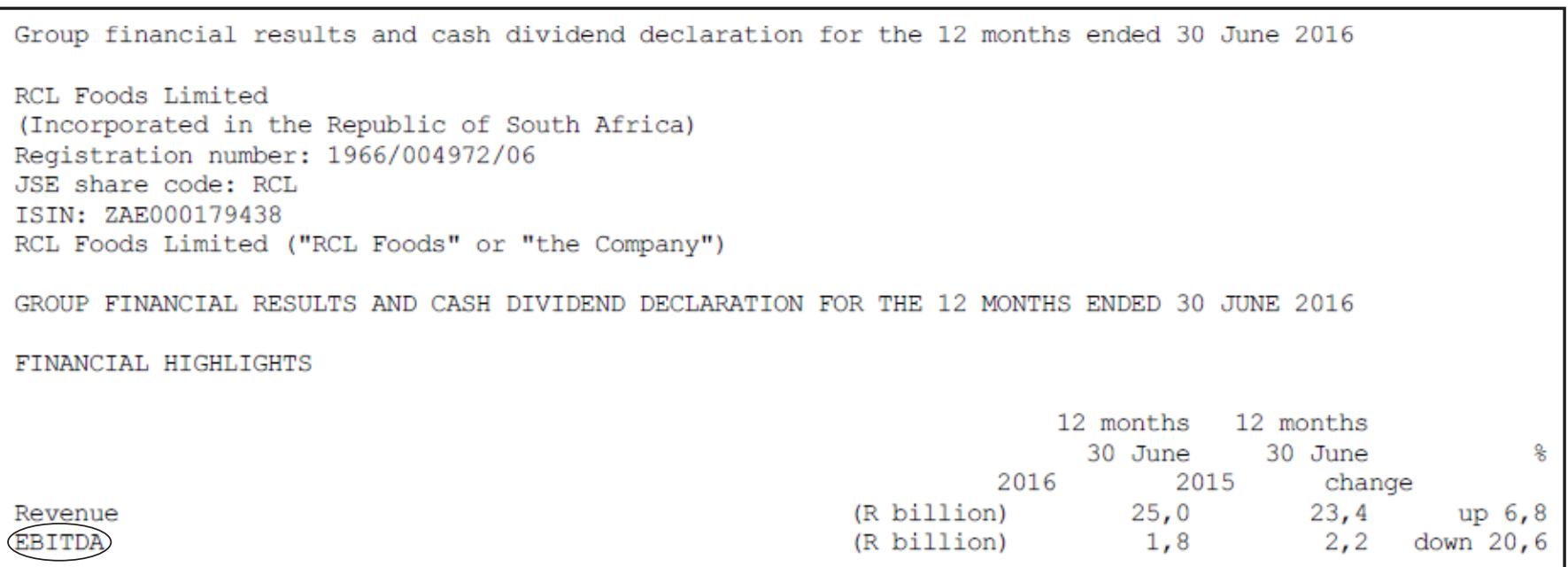

Source: RCL Foods Limited, 2016, SENS report - Group financial results and cash dividend declaration for the 12 months ended 30 June 2016, IRESS Expert, Johannesburg. Authors' emphasis. FIGURE 1: Extract from RCL Foods Limited 2016 Stock Exchange News Service report - Example of an unmodified earnings before interest, tax, depreciation and amortisation label.

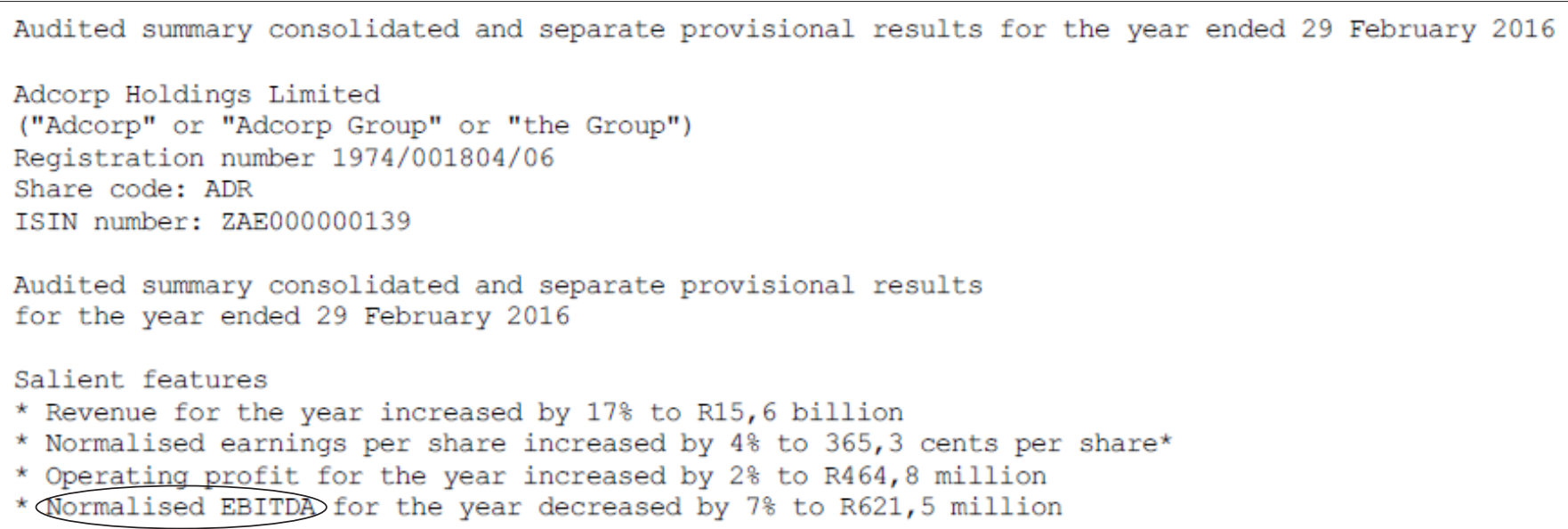

Source: Adcorp Holdings Limited, 2016, SENS report - Audited summary consolidated and separate provisional results for the year ended 29 February 2016, IRESS Expert, Johannesburg. Authors' emphasis. FIGURE 2: Extract from Adcorp Holdings Limited 2016 Stock Exchange News Service report - example of a modified earnings before interest, tax, depreciation and amortisation label.

In contrast to the previous example, in its 2016 SENS report, Adcorp Holdings Limited narratively defined 'normalised EBITDA' (as shown in Figure 2) as 'EBITDA excluding sharebased payments, lease smoothing, and establishment and transaction costs'.

\section{Research objective 3}

The third and last research objective was to recalculate the amount disclosed as EBITDA, by using the definition of EBITDA disclosed in a SENS report. This objective was only performed for SENS reports that disclosed an unmodified EBITDA label. By recalculating EBITDA based on the definition disclosed, any inconsistencies between how those SENS reports labelled, defined and calculated EBITDA could be assessed. For example, the 2014 SENS report of MTN Group Limited disclosed an unmodified EBITDA label, but defined EBITDA as 'Earnings before interest, tax, depreciation and amortisation and goodwill impairment' (MTN Group Limited 2014). Based on the definition provided, it was expected that the amount disclosed for EBITDA would include an adjustment for goodwill impairment together with the other ITDA-adjustments. Consequently, an attempt was made to recalculate the EBITDA amount by using the adjustments stated in the definition provided by the company.

Where no definition was provided, or where the amount was not included as a line item in either the income statement or in a tabular reconciliation, it was assumed that the company implicitly defined EBITDA as IFRS earnings from continuing operations before interest, tax, depreciation and amortisation. For example, the 2015 SENS report of Omnia Holdings Limited disclosed an unmodified EBITDA label and provided no definition, nor reconciliation to IFRS earnings (Omnia Holdings Limited 2015). In such an instance, a recalculation of the EBITDA amount was attempted by using the amounts for interest, tax, depreciation and amortisation as obtained from the income statement and related notes.

\section{Data analysis}

Descriptive statistics, namely frequency tables and graphical figures depicting frequencies, were used as a primary form 
of analysis necessary to achieve the research objectives (Saunders, Lewis \& Thornhill 2016:553). Initially, frequency tables were used to describe how companies labelled EBITDA. A list of EBITDA definitions was then compiled to assess potential diversity in how companies define EBITDA, after which the frequency of inconsistencies between the EBITDA labels and definitions was tabled. Lastly, EBITDA was recalculated in terms of the definition provided and the results of inconsistencies were graphically linked to provide descriptive evidence necessary to determine the extent to which companies labelled, defined and calculated EBITDA in an inconsistent manner.

\section{Data quality and integrity}

To limit the risk of inconsistencies arising from using more than one researcher, only one researcher was involved in compiling the EBITDA labels and definitions from the SENS reports. The risk of data capturing errors was addressed by having an independent person verify, on a random basis, the data captured (Bryman 2012:304). In addition, the 'codebook' function of the statistical software STATA was used to identify any instances of missing data entries, which were then rectified.

\section{Ethical consideration}

Ethical approval to conduct the study was obtained from the Humanities Research Ethics Committee at Stellenbosch University (approval number: ACC-2017-0861-506) on 28 August 2017.

\section{Results and discussion}

\section{Research objective 1: Describe how SENS reports labelled earnings before interest, tax, depreciation and amortisation}

The first research objective was met by describing how SENS reports labelled EBITDA when discussing company performance. Table 3 lists the nature and frequency of the various EBITDA labels identified in the 220 SENS reports' performance discussions. The occurrences of the various labels used in the SENS reports are provided per year and in total and sorted from most frequent to the least frequent.

As indicated in Table 3, the results show that $74 \%$ of the total population (163 of 220 SENS reports over the period 2014-2016) disclosed an unmodified EBITDA label when discussing the performance of a company. The remaining 57 SENS reports $(26 \%$ of 220 ) disclosed a modified EBITDA label that indicated that adjustments other than ITDAadjustments were also made. Although not directly comparable, these findings are somewhat consistent with Isidro and Marques' (2015) finding, where 39\% of their sample of European companies disclosed modified labels for earnings before interest and tax (EBIT) and EBITDA. By disclosing modified EBITDA labels, the 57 SENS reports clearly informed users not to expect a standardised EBITDA calculation. Whether the 163 SENS reports that disclosed an unmodified EBITDA label provided a faithful representation by defining

TABLE 3: List of earnings before interest, tax, depreciation and amortisation labels in Stock Exchange News Service reports and the frequency of occurrences per year for the period 2014-2016 $(N=220)$.

\begin{tabular}{|c|c|c|c|c|c|}
\hline \multicolumn{2}{|c|}{ Number EBITDA LABEL } & 2014 & 2015 & 2016 & Total \\
\hline \multicolumn{6}{|c|}{ Unmodified EBITDA label disclosed in 163 SENS reports } \\
\hline 1 & EBITDA & 53 & 56 & 54 & 163 \\
\hline \multicolumn{6}{|c|}{ Modified EBITDA labels disclosed in 57 SENS reports } \\
\hline 2 & Adjusted EBITDA & 5 & 5 & 7 & 17 \\
\hline 3 & Normalised EBITDA & 5 & 3 & 5 & 13 \\
\hline 4 & Underlying EBITDA & 3 & 3 & 5 & 11 \\
\hline 5 & EBITDA excluding special items & 1 & 1 & 1 & 3 \\
\hline 6 & Operational EBITDA & 1 & 1 & 1 & 3 \\
\hline 7 & Core EBITDA & 0 & 1 & 1 & 2 \\
\hline 8 & EBITDA before capital items & 0 & 1 & 1 & 2 \\
\hline 9 & $\begin{array}{l}\text { EBITDA excluding special items and } \\
\text { income from associates and joint } \\
\text { ventures }\end{array}$ & 0 & 1 & 1 & 2 \\
\hline 10 & EBITDA from continuing operations & 1 & 0 & 0 & 1 \\
\hline 11 & EBITDA excluding once-off items & 1 & 0 & 0 & 1 \\
\hline 12 & Headline EBITDA & 1 & 0 & 0 & 1 \\
\hline 13 & Operating EBITDA & 0 & 0 & 1 & 1 \\
\hline Total & - & 71 & 72 & 77 & 220 \\
\hline
\end{tabular}

EBITDA, earnings before interest, tax, depreciation and amortisation.

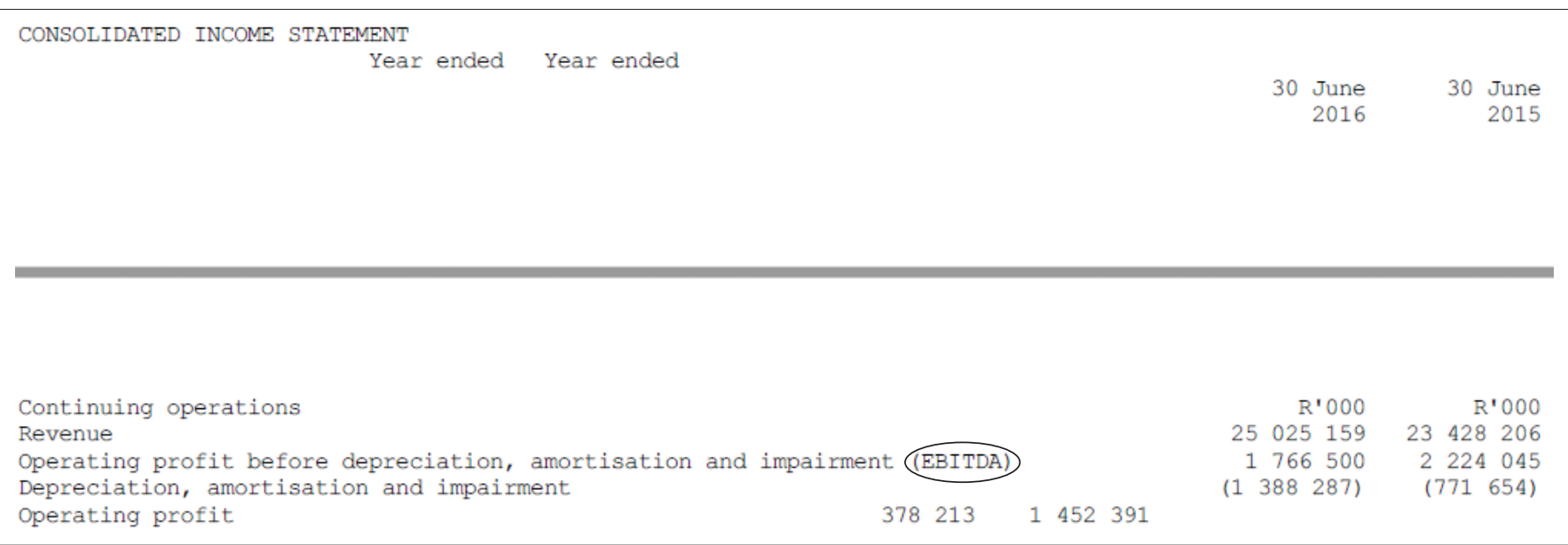

Source: RCL Foods Limited, 2016, SENS report - Group financial results and cash dividend declaration for the 12 months ended 30 June 2016, IRESS Expert, Johannesburg. Authors' emphasis. FIGURE 3: Extract from RCL Foods Limited 2016 Stock Exchange News Service report - example of how earnings before interest, tax, depreciation and amortisation was defined. 
and calculating EBITDA in a manner consistent with the label is addressed with research objectives 2 and 3 below.

\section{Research objective 2: Identify how Stock Exchange News Service reports defined earnings before interest, tax, depreciation and amortisation}

The purpose of the second objective was to identify how SENS reports defined EBITDA to assess the congruency between the label and definition and to assess the diversity in how companies defined EBITDA. Figure 4 provides a link between research objective 1 (modified or unmodified labels) and research objective 2 (how the label was defined).

Of particular interest was the 163 SENS reports $(74 \%$ of the population) from research objective 1 that disclosed an unmodified EBITDA label. When an unmodified EBITDA label was disclosed in a SENS report, users of the SENS report may be inclined to assume that the only adjustments made in calculating EBITDA were ITDA-adjustments. Contrast this with a modified EBITDA label, for example, 'EBITDA excluding once-off items', which provides a clear indication that EBITDA is calculated not only by adjusting for ITDAadjustments, but also by making other adjustments. Figure 4 shows that of the 163 SENS reports, 63 (29\% of 220$)$ SENS reports disclosed the standard definition of EBITDA (i.e. earnings before interest, tax, depreciation and amortisation), 48 (22\% of 220) SENS reports disclosed no definition and used the acronym 'EBITDA' throughout the report and 52 (24\% of 220) SENS reports included definitions showing that EBITDA was calculated not only as earnings before ITDAadjustments, but also with other adjustments. Definitions provided in these 52 reports varied widely, with 27 different definitions of EBITDA identified. This key finding highlights the risk of users assuming EBITDA to be a standardised measure.
The remaining 57 SENS reports identified from research objective 1, that is, those that disclosed a modified EBITDA label, also differed widely in how the modified EBITDA measure was defined. Arguably, these SENS reports facilitated a faithful representation by not only presenting a label that informed users of additional adjustments (other than ITDA-adjustments), but also by disclosing a definition of how the measure was calculated. For the 57 SENS reports, 23 different definitions of the modified EBITDA measure were identified. Although it may be expected that the nature of companies' expenses and transactions differ, such wide diversity in definitions of modified EBITDA is surprising as the IASB has identified only limited number of adjusting items (other than ITDA-adjustments) that companies routinely make (IASB 2016). In total, 50 different definitions of EBITDA, whether the label was presented as modified or unmodified, were identified and are depicted in Table 4.

Panel A of Table 4 lists the 27 definitions pertaining to SENS reports that disclosed an unmodified EBITDA label and Panel B lists the 23 definitions pertaining to SENS reports that disclosed a modified EBITDA label. Although a further analysis of the types of and the reason for adjustments between EBITDA and IFRS earnings falls outside the scope of this study, the purpose of Table 4 is to illustrate the extent of differences in the EBITDA-definitions. Sub-categories are provided in both panels to reflect the extent to which EBITDA was defined in terms of 'bottom-line earnings', 'operating profit or loss' and 'other terms'. As operating profit or loss is undefined in IFRS, defining EBITDA in terms of operating profit or loss does not enhance its decision-usefulness.

The diversity in definitions listed in Table 4 reaffirms concerns already raised about the lack of comparability of EBITDA between companies. Table 4 further shows that many SENS reports defined EBITDA in terms of operating

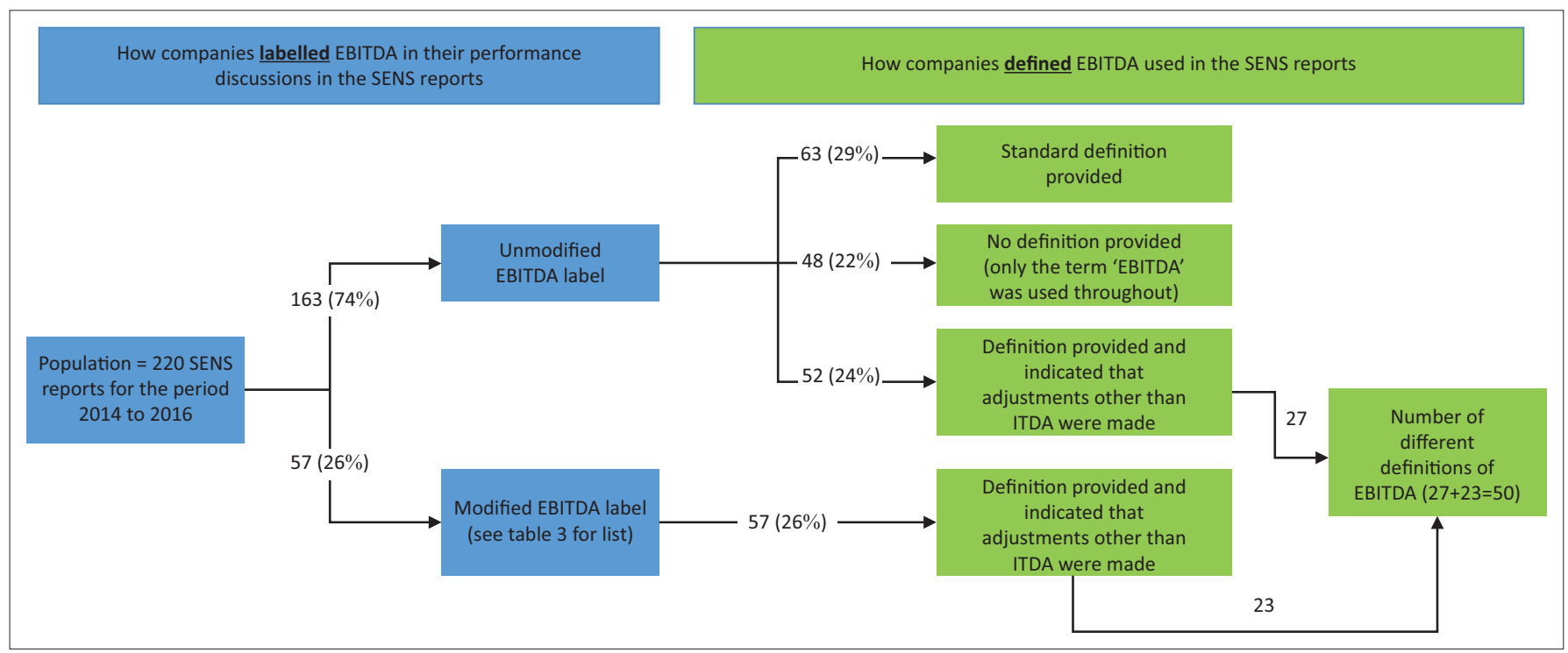

EBITDA, earnings before interest, tax, depreciation and amortisation; ITDA, interest, tax, depreciation and amortisation; SENS, Stock Exchange News Service. Note: All percentages expressed as a proportion of the total population of 220.

FIGURE 4: Summary of how companies labelled and defined earnings before interest, tax, depreciation and amortisation in their Stock Exchange News Service reports from 2014 to $2016(N=220)$. 
TABLE 4a: List of non-standard definitions of earnings before interest, tax, depreciation and amortisation in Stock Exchange News Service reports from 2014 to 2016 $(N=220)$.

Number Panel A: Definitions of EBITDA as provided in the SENS reports in which an unmodified EBITDA label was disclosed

\section{EBITDA defined in terms of bottom-line earnings}

Earnings before interest, tax and depreciation. investments.

Earnings before tax, depreciation and amortisation.

Net operating earnings before depreciation and amortisation

Net operating income.

Operating profit or loss before depreciation and amortisation. profits.

Earnings after Black Economic Empowerment (BEE) transactions but before interest, tax and depreciation.

Earnings before interest, impairments, tax, depreciation and amortisation.

Earnings before interest, tax, depreciation and amortisation and adding back: Impairment or reversal of an impairment of an asset, fair value adjustments to financial instruments, stock-based compensation, foreign exchange gains and losses and non-recurring transaction expenses or income.

Earnings before interest, tax, depreciation and amortisation and excluding foreign exchange movements.

Earnings before interest, tax, depreciation and amortisation and goodwill impairment losses.

Earnings before interest, tax, depreciation and amortisation and impairments of subsidiaries and includes a share in EBITDA before impairments in equity-accounted

Earnings before interest, tax, depreciation and amortisation excluding exceptional items and income from associates and joint ventures.

Earnings before interest, tax, depreciation and amortisation from core operations.

Earnings before interest, tax, depreciation and amortisation, fair value and impairment adjustments.

Earnings before interest, tax, depreciation and amortisation, impairments and before foreign exchange gains or losses.

Earnings before interest, tax, depreciation, amortisation and capital items.

Earnings before interest, tax, depreciation, amortisation, impairment of goodwill, net monetary gains and share of results of joint ventures and associates.

Operating earnings before interest, tax, depreciation and amortisation.

Operating profit or loss before depreciation, amortisation and capital items.

Operating profit or loss before depreciation, amortisation and impairment.

Operating profit or loss before depreciation, amortisation, impairment of goodwill, intangibles, property, plant and equipment.

Operating profit or loss before finance costs, depreciation and amortisation

Operating profit or loss before interest, tax, depreciation and amortisation.

Operating profit or loss before interest, tax, depreciation and amortisation and including unrealised foreign exchange gain.

Operating profit or loss before interest, tax, depreciation and amortisation, impairment losses, unrealised foreign exchange differences on loans and equity-accounted

Operating profit or loss before interest, tax, depreciation, amortisation, impairment losses, foreign exchange differences and equity-accounted profit or losses.

TABLE 4b: List of non-standard definitions of earnings before interest, tax, depreciation and amortisation in Stock Exchange News Service reports from 2014 to 2016 ( $N=220$ ).

\section{Number Panel B: Definitions of EBITDA as provided in the SENS reports in which a modified EBITDA label was disclosed}

\section{EBITDA defined in terms of bottom-line earnings}

Earnings after BEE charges but before interest, tax and depreciation.

Earnings before interest (net finance cost), taxation, depreciation, amortisation and special items.

Earnings before interest, tax, depreciation and amortisation adjusted for IFRS 2 charge, straightlining of lease and goodwill impairment.

Earnings before interest, tax, depreciation and amortisation and special items.

Earnings before interest, tax, depreciation and amortisation before special items and re-measurements.

Earnings before interest, tax, depreciation and amortisation before transaction costs.

Earnings before interest, tax, depreciation and amortisation excluding special items and income from associates and joint ventures.

Earnings before interest, tax, depreciation and amortisation, bargain purchase gain, impairments and loss on disposal of assets held for sale.

Earnings before interest, tax, depreciation, amortisation, impairments and loss on disposal of associate.

Profit for the period before income taxes, net finance income or (costs) including foreign exchange gains or (losses), depreciation of property, plant and equipment including capitalised customer in-vehicle devices, amortisation of intangible assets including capitalised in-house development costs and intangible assets identified as part of a business combination, share-based compensation costs, transaction costs arising from the acquisition of a business or investigating strategic alternatives, restructuring costs, profits or (losses) on the disposal or impairments of assets or subsidiaries, insurance reimbursements relating to impaired assets and certain litigation costs.

\section{EBITDA defined in terms of operating profit or loss}

11 Operating profit or loss before depreciation, amortisation, special items and remeasurements.

12 Operating profit or loss before special items, depreciation and amortisation.

13 Operating profit or loss plus depreciation, amortisation of intangible assets, impairment of property, plant and equipment and excluding profit or loss and fair value adjustments on the disposal of businesses, fair value adjustments, transaction costs and surpluses or deficits on retirement benefits.

EBITDA defined in terms of other references

14 Adjusted earnings before interest, tax, depreciation and amortisation.

15 Adjusted earnings before interest and tax (EBIT) is revenue less cost of goods sold and selling and administrative expenses plus share of income from associates and joint ventures, dividend income and the attributable share of underlying Adjusted EBIT of certain associates and joint ventures and the discontinued Agricultural products segment, excluding significant items. Adjusted EBITDA consists of Adjusted EBIT plus depreciation and amortisation.

16 Adjusted EBITDA is defined as earnings before interest, tax, depreciation and amortisation and adding back the following: Impairment or reversal of an impairment of an asset, fair value adjustments to financial instruments, stock-based compensation, foreign exchange gains and losses and non-recurring transaction expenses or income.

17 Core earnings before interest, tax, depreciation and amortisation.

Table $4 \mathrm{~b}$ continues on the next page $\rightarrow$ 
TABLE 4b (Continues...): List of non-standard definitions of earnings before interest, tax, depreciation and amortisation in Stock Exchange News Service reports from 2014 to $2016(N=220)$.

Number Panel B: Definitions of EBITDA as provided in the SENS reports in which a modified EBITDA label was disclosed

$18 \quad$ Normalised earnings before interest, tax, depreciation and amortisation.

19 Normalised earnings before interest, tax, depreciation excluding share-based payments, lease smoothing and transaction costs.

20 Trading operating profit or loss before depreciation and amortisation.

21 Underlying EBIT before depreciation, amortisation and impairments. Underlying EBITDA is reported before net finance costs and taxation benefit or

(expense),depreciation, amortisation and impairments related to equity-accounted investments and excludes exceptional items.

EBITDA defined in terms of other references

22 Underlying EBIT before depreciation and amortisation. Underlying EBIT is profit from continuing operations before interest, tax and earnings adjustments, including impairments, but includes a share in equity-accounted interest and tax.

23 Underlying EBIT before depreciation, impairments and amortisation.

EBIDTA, earnings before interest, tax, depreciation and amortisation.

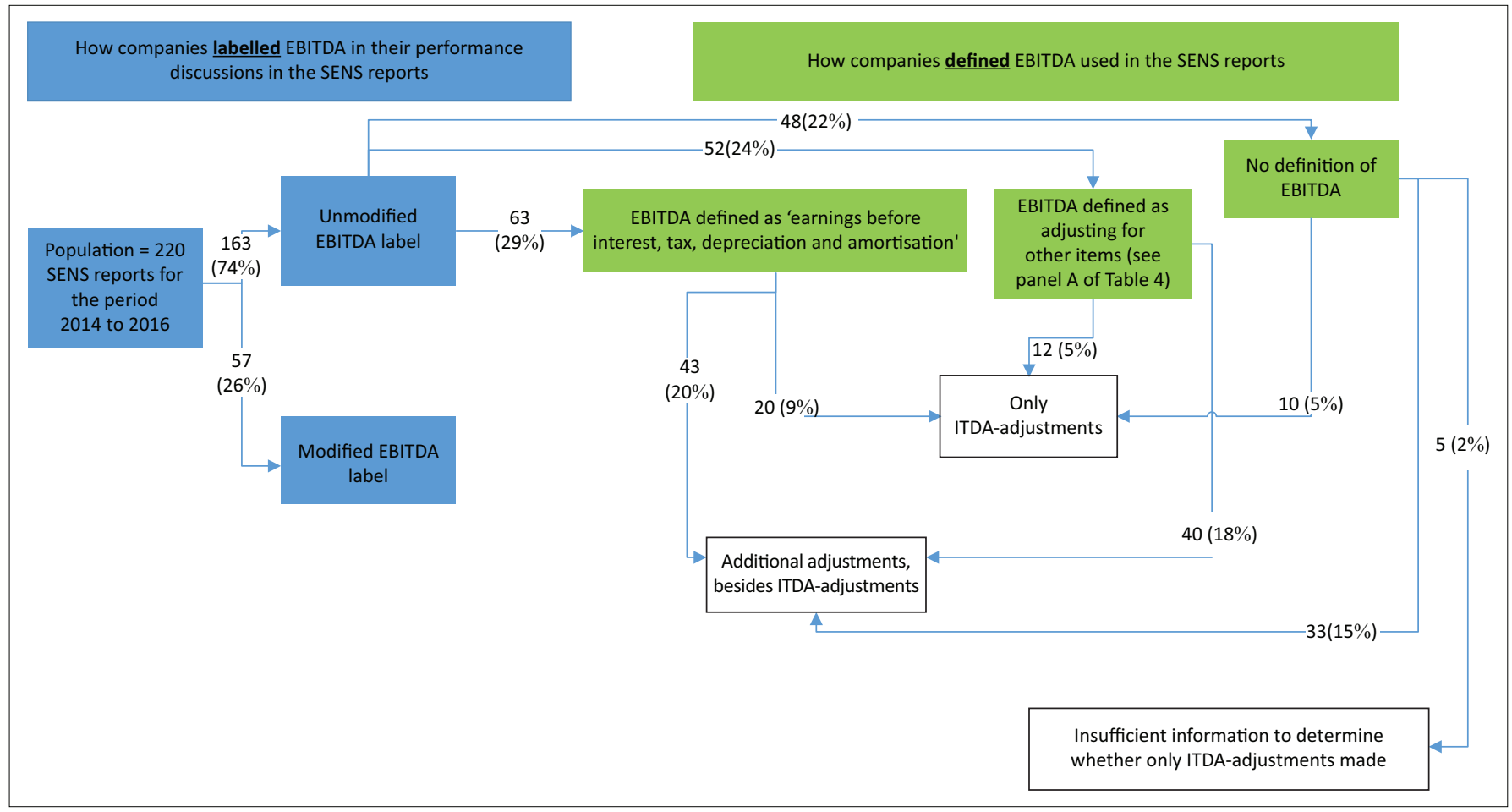

ITDA, interest, tax, depreciation and amortisation; EBITDA, earnings before interest, tax, depreciation and amortisation

Note: All percentages expressed as a proportion of the total population of 220.

FIGURE 5: Discrepancies between how Stock Exchange News Service reports labelled, defined and calculated earnings before interest, tax, depreciation and amortisation for the period 2014-2016 $(N=220)$.

income and not bottom-line earnings. This misrepresentation of EBITDA detracts from faithfully representing the measure, which is why the SEC prohibits US-listed companies from reconciling EBITDA to operating profit (SEC 2018). The results from achieving research objective 2 not only point to a lack of comparability, but suggest that EBITDA is not being faithfully represented, particularly when SENS reports disclose an unmodified EBITDA label, but define EBITDA as adjusting for items other than ITDAadjustments as well.

\section{Research objective 3: Recalculate earnings before interest, tax, depreciation and amortisation based on the definition provided in the SENS report}

The third research objective was to recalculate EBITDA for SENS reports that disclosed an unmodified EBITDA label. In achieving the objective, an assessment could be made about the extent to which these SENS reports labelled, defined and calculated EBITDA in a consistent manner. Figure 5 continues from Figure 4, links the findings from objectives 1 and 2 to the findings from achieving objective 3 and highlights the discrepancies between how SENS reports labelled, defined and calculated EBITDA in instances where an unmodified EBITDA label was disclosed.

Figure 5 shows that of the 63 SENS reports that disclosed an unmodified EBITDA label and provided the standard definition of EBITDA, 43 (20\% of the population) SENS reports adjusted for items other than ITDA-adjustments. The remaining 20 of 63 SENS reports (9\% of the population) made ITDA-adjustments only, consistent with the unmodified EBITDA label and definition.

Of the 52 SENS reports that disclosed an unmodified EBITDA label and disclosed a definition that indicated that EBITDA was adjusted for items other than ITDA-adjustments, 12 (5\% of the population) did not adjust for the other items. This was despite the additional adjustments being indicated in the 
narrative definition and it shows that companies are inconsistent how they define and calculate EBITDA.

The last group of SENS reports in Figure 5 of particular interest was the 48 of 163 SENS reports that disclosed an unmodified EBITDA label, without disclosing any definition. Five SENS reports lacked the information necessary to reconcile EBITDA to IFRS earnings and, thereby, determine whether ITDA-adjustments only were made. Thirty-three (15\% of the population) of the 48 SENS reports adjusted not only for ITDA-adjustments, but also other items. Upon further scrutiny of the 33 SENS reports, it was found that 16 disclosed a reconciliation that enabled a recalculation of EBITDA. Therefore, although the unmodified EBITDA label was not supported by any definition, the reconciliation provided the information necessary to understand how the EBITDA measure was calculated. Despite the reconciling information, users who fixate on the unmodified EBITDA label, without careful scrutiny of the SENS report, would mistakenly assume a standardised calculation. The remaining 17 ( $8 \%$ of the population) of the 33 SENS reports provided no reconciliation. However, after also adjusting for impairment losses, profits or losses from the sale of assets, equity accounted profits or losses, fair value adjustments on financial instruments and foreign exchange gains or losses, it was possible to reconcile the EBITDA to the IFRS profit or loss in 8 of the 17 SENS reports. This finding confirms that of the IASB that companies regularly adjust for these items when calculating EBITDA although they do not explicitly state that they are doing so (IASB 2016). It should, however, not be assumed that all companies adjust for these items. Although the last 10 (5\% of the population) out of the 48 SENS reports adjusted for ITDA-adjustments only, consistent with the measurement implied by the unmodified EBITDA label, five disclosed items such as impairment losses and fair value adjustments on financial instruments but did not adjust for it in EBITDA. For example, the 2016 SENS report of Tharisa Plc (2016) revealed that the company had incurred impairment losses and fair value adjustments on financial instruments, but had not added these back when calculating EBITDA. Similarly, the 2015 SENS report of Omnia Holdings Limited (2015) showed that the company had a profit on disposal of assets as well as impairments losses, neither of which was adjusted for in calculating the EBITDA amount as disclosed.

Collectively, the results from the third research objective show that the SENS reports of companies that present an unmodified EBITDA label, implying a standardised calculation, lack a faithful representation of EBITDA. This finding underscores the risk identified in other studies that EBITDA, although presented as a standardised measure, include other undisclosed adjustments (CFA Society United Kingdom 2015). Although the IASB has identified some adjustments that companies routinely make in calculating EBITDA, the results here show that companies are inconsistent in whether those adjustments are taken into account. These inconsistencies further hamper comparability of EBITDA.

\section{Practical implications}

The results from this study show that the users of South African companies' SENS reports should be wary of assuming that EBITDA is a standardised, well-defined measure - in other words, as a performance measure derived from IFRS earnings by adjusting only for interest, tax, depreciation and amortisation. This finding has implications for investors, lenders and where executive compensation contracts are based on EBITDA. Investors who use EBITDA as a valuation tool should pay particular attention to the label, the definition applied to the label as well as the type of adjustments companies make in calculating EBITDA. This is of particular concern for less-sophisticated users of financial reports when those users fixate on prominently displayed earnings measurements and ignore other relevant information elsewhere in the financial report (Johnson \& Schwartz 2005; Young 2014). Likewise, lenders who use EBITDA as a performance measure in debt covenants should be careful to explicitly define EBITDA to enable effective monitoring. Lastly, it may be necessary to explicitly define EBITDA where it is used as a performance indicator in executive compensation contracts.

The results from this study further suggest that existing JSE reporting requirements are not explicit enough to ensure that companies' EBITDAdisclosure exhibit a faithful representation that facilitates decision-useful information. Whether the JSE's (JSE 2019) proposed revision to its disclosure requirements on non-GAAP earnings will be adequate to address the identified inconsistencies, is yet to be seen.

The inconsistent manner between how EBITDA is labelled, defined and calculated makes it difficult, or arguably impossible to compare EBITDA between companies. The result further underscores the importance of requiring companies to disclose a detailed reconciliation between EBITDA and IFRS earnings in order to ensure decision-useful information. This would be in line with the IASB's disclosure initiative (IASB 2017a) as well as the proposed revision to the JSE's disclosure requirements on non-GAAP earnings (JSE 2019) to improve the quality of disclosure in financial reports. Doing so will enable comparability and enhance the decision-usefulness of the EBITDA measure.

Some stakeholders have requested the IASB to develop a standardised definition of EBITDA (IASB 2017a). However, the wide diversity found in how companies define EBITDA casts serious doubt of whether such a goal will ever be attainable. Instead, the results provide support for the development of a disclosure requirement that mandates companies to disclose a detailed reconciliation between IFRS earnings and EBITDA.

\section{Limitations and recommendations}

Although this study showed that diversity exists in how companies label, define and calculate EBITDA, it did not assess whether users were confounded by the inconsistent disclosure. Further research could shed light on how users, 
particularly less-sophisticated users, react to the reporting quality of EBITDA disclosure.

Caution should be taken to extend the findings to financial reports other than SENS reports. This study only focussed on SENS reports issued by JSE-listed companies. Such SENS reports are not required to be audited and provide management with more leeway in how EBITDA is disclosed. Whether the identified inconsistencies in EBITDA disclosure exist in other financial reports (e.g. annual reports) remains open to further research.

Lastly, this study focussed on the role of EBITDA as a nonGAAP earnings measure to convey information to users. Voluntary disclosure literature provides a contrary reason for management to disclose non-GAAP earnings; that is, to disclose non-GAAP earnings so as to influence users' perceptions of companies' performance (Young 2014). The question of whether the inconsistent disclosure between how companies label, define and calculate EBITDA is a result of management's attempt to manage users' perceptions remains open for further research.

\section{Conclusion}

The purpose of this study was to answer the research question of whether EBITDA disclosure by JSE-listed companies is decision-useful. Two concepts underlying decisionusefulness were assessed, namely faithful representation and comparability. Through quantitative content analysis, 220 SENS reports containing the annual results of JSE-listed companies for the financial years 2014-2016 were analysed to determine whether companies labelled, defined and calculated EBITDA in a consistent manner. Descriptive evidence showed that JSE-listed companies were inconsistent in how they labelled, defined and calculated EBITDA. The results identified wide diversity in how companies defined EBITDA, indicating a lack of comparability. In addition, the results showed that EBITDA disclosure was not being faithfully represented in the SENS reports of JSE-listed companies. The inconsistent manner in which SENS reports labelled, defined and calculated EBITDA provides evidence of the lack of decision-usefulness, thereby answering the research question. In ensuring transparent reporting practices that facilitate decision-useful information, it is recommended that the JSE provides explicit disclosure requirements on EBITDA reporting. Lastly, the results act as a warning to users of financial reports when assuming that EBITDA is calculated as earnings before interest, tax, depreciation and amortisation.

\section{Acknowledgements Competing interests}

The authors have declared that no competing interest exists.

\section{Authors' contributions}

M.T.M. authored the manuscript. C.L. provided strategic input and edited the manuscript.

\section{Funding information}

This research received no specific grant from any funding agency in the public, commercial or not-for-profit sectors.

\section{Data availability statement}

A summary of the coded data can be made available from the corresponding author upon request.

\section{Disclaimer}

The views and opinions expressed in this article are those of the authors and do not necessarily reflect the official position of any affiliated agency of the authors.

\section{References}

Adcorp Holdings Limited, 2016, SENS report - Audited summary consolidated and separate provisional results for the year ended 29 February 2016, IRESS Expert, Johannesburg.

Allee, K.D., Bhattacharya, N., Black, E.L. \& Christensen, T.E., 2007, 'Pro forma disclosure and investor sophistication: External validation of experimental evidence using archival data', Accounting, Organizations and Society 32(3), 201-222. https://doi. archival data', Accounting, Organiz
org/10.1016/j.aos.2006.09.012

Aubert, F. \& Grudnitski, G., 2014, 'The role of reconciliation quality in limiting mispricing of non-GAAP earnings announcements by EURO STOXX firms', Advances in Accounting 30(1), 154-167. https://doi.org/10.1016/j.adiac.2014.03.008

Beattie, V., 2014, 'Accounting narratives and the narrative turn in accounting research: Issues, theory, methodology, methods and a research framework', British Accounting Review 46(2), 111-134. https://doi.org/10.1016/j.bar.2014.05.001

Bhattacharya, N., Black, E.L., Christensen, T.E. \& Mergenthaler, R.D., 2004, 'Empirical evidence on recent trends in pro forma reporting', Accounting Horizons 18(1), 27-43. https://doi.org/10.2308/acch.2004.18.1.27

Brown, S., 2016, Getting to grips with EBITDA, viewed 30 April 2019, from https:// www.fin 24 .com/Finweek/Personal-finance/getting-to-grips-withebitda-20161208.

Bryman, A., 2012, Social research methods, 4th edn., Oxford University Press, New York, NY.

Cameron, R., 2012, 'Do large Australian companies emphasise nongaap financial measures over statutory net profit (GAAP) in annual reports?', JASSA the Finsia Journal of Applied Finance Issue 1(1), 13-19.

Cascino, S., Clatworthy, M., Osma, B.G., Gassen, J., Imam, S. \& Jeanjean, T., 2016 Professional investors and the decision usefulness of financial reporting, ICAS, viewed 10 April 2017, from https://www.icas.com/technical-resources/ professional-investors-and-the-decision-usefulness-of-financial-reporting.

CFA Society United Kingdom, 2015, Non-IFRS earnings and alternative performance measures: Ensuring a level playing field, London, viewed 27 June 2017, from https://secure.cfauk.org/assets/1345/Non_IFRS_Earnings_and_Alternative _ Performance_Measures_FINAL_web.pdf.

D'Souza, J., Ramesh, K. \& Shen, M., 2010, 'Disclosure of GAAP line items in earnings announcements', Review of Accounting Studies 15(1), 179-219. https://doi. org/10.1007/s11142-009-9100-0

Elliott, W.B., 2006, 'Are investors influenced by pro forma emphasis and reconciliations in earnings announcements?', Accounting Review 81(1), 113-133. https://doi. org/10.2308/accr.2006.81.1.113

Entwistle, G.M., Feltham, G.D. \& Mbagwu, C., 2005, 'The voluntary disclosure of pro forma earnings: A U.S.-Canada comparison', Journal of International Accounting Research 4(2), 1-23. https://doi.org/10.2308/jiar.2005.4.2.1

Entwistle, G.M., Feltham, G.D. \& Mbagwu, C., 2010, 'The value relevance of alternative earnings measures: A comparison of pro forma, GAAP, and $1 / B / E / S$ earnings', Journal of Accounting, Auditing \& Finance 25(2), 261-288. https://doi.org/10. Journal of Accounting, Auditing
$1177 / 0148558 \times 1002500205$

Graham, J.R., Harvey, C.R. \& Rajgopal, S., 2005, 'The economic implications of corporate financial reporting', Journal of Accounting and Economics 40(1), 3-73. https://doi.org/10.1016/j.jacceco.2005.01.002

Hattingh, C., 2012, Why we need to abandon EBITDA X 4, viewed 30 April 2019, from http://www.gaaaccounting.com/why-we-need-to-abandon-ebitda-x-4/.

Healy, P.M. \& Palepu, K.G., 2001, 'Information asymmetry, corporate disclosure, and the capital markets: A review of the empirical disclosure literature', Journal of Accounting and Economics 31(1-3), 405-440. https://doi.org/10.1016/S01654101(01)00018-0

Hitz, J.-M., 2010, 'Press release disclosure of "pro forma" earnings metrics by large German corporations - Empirical evidence and regulatory recommendations', Accounting in Europe 7(1), 63-86. https://doi.org/10.1080/17449480.2010.48 5376

Howard, M., Maroun, W. \& Garnett, R., 2019, 'Misuse of non-mandatory earnings reporting by companies: Evidence from an emerging economy', Meditari Accountancy Research 27(1), 125-146. https://doi.org/10.1108/MEDAR-12-2017-0247 
International Accounting Standards Board (IASB), 2016, Staff paper 21B November 2016: Primary Financial Statements - Use of performance measures, viewed 10 April 2017, from https://www.ifrs.org/projects/work-plan/primary-financial10 April 2017, from h
statements/\#meetings.

International Accounting Standards Board (IASB), 2017a, Discussion paper DP/2017/1: Disclosure initiative - Principles of disclosure, viewed 03 April 2017, from http:// www.ifrs.org/Current-Projects/IASB-Projects/Disclosure-Initiative/Principles-ofDisclosure/Pages/Home.aspx.

International Accounting Standards Board (IASB), 2017b, IAS 34 - Interim financial reporting, IFRS Foundation, London.

International Accounting Standards Board (IASB), 2018, Conceptual framework for financial reporting, viewed 10 August 2018, from http://eifrs.ifrs.org/eifrs/Menu? ref $=29 \mathrm{cb} 9$ fe\&token=Mzc40TY5NzA\%3D.

Isidro, H. \& Marques, A., 2013, 'The effects of compensation and board quality on non-GAAP disclosures in Europe', International Journal of Accounting 48(3), 289-317. https://doi.org/10.1016/j.intacc.2013.07.004

Isidro, H. \& Marques, A., 2015, 'The role of institutional and economic factors in the strategic use of non-GAAP disclosures to beat earnings benchmarks', European Accounting Review 24(1), 95. https://doi.org/10.1080/09638180.2014.894928

Johannesburg Stock Exchange Limited (JSE), 2017, JSE Limited listings requirements, viewed 04 September 2018, from http://www.jse.co.za/content/ JSERulesPoliciesandRegulationltems/JSERequirements.pdf.

Johannesburg Stock Exchange Limited (JSE), 2019, Amendments to JSE listing requirements (the 'requirements') performance measurers May 2019, viewed 18 June 2019, from https://www.jse.co.za/content/JSEAnnouncementltems/ Explanatory Memorandum May 2019.pdf.

Johnson, W.B. \& Schwartz, W.C., Jr., 2005, 'Are investors misled by "pro forma" earnings?', Contemporary Accounting Research 24(4), 915-963. https://doi.org/ 10.1506/CKET-2ERA-NNRP-ATXF

Malone, L., Tarca, A. \& Wee, M., 2016, 'IFRS non-GAAP earnings disclosures and fair value measurement', Accounting and Finance 56(1), 59-97. https://doi.org/ 10.1111/acfi.12204

MTN Group Limited, 2014, SENS report - Summary consolidated annual financial results for the year ended 31 December 2014, IRESS Expert, Johannesburg.

O'Regan, P., 2006, Financial information analysis, 2nd edn., Wiley, Chichester.

Omnia Holdings Limited, 2015, SENS report - Audited results for the year ended 31 March 2015, IRESS Expert, Johannesburg.
Papa, V.T., Peters, S.J \& Schacht, K., 2016, Investor uses, expectations, and concerns on non-GAAP financial measures, CFA Institute, viewed 10 April 2017, from https:// www.cfapubs.org/doi/pdf/10.2469/ccb.v2016.n11.1.

PWC, 2014, Corporate performance: What do investors want to know? Reporting adjusted performance measures, viewed 14 June 2016, from http://www.pwc. com/en GX/gx/audit-services/corporate-reporting/publications/investor-view/ assets/pwc-investor-survey-ir-september2014.pdf.

Rainsbury, L., Hart, C. \& Buranavityawut, N., 2015, ‘GAAP-adjusted earnings disclosures by New Zealand companies', Pacific Accounting Review 27(3), 329-352. https://doi.org/10.1108/PAR-12-2013-0108

RCL Foods Limited, 2016, SENS report - Group financial results and cash dividend declaration for the 12 months ended 30 June 2016, IRESS Expert, Johannesburg.

Rozenbaum, O., 2019, 'EBITDA and managers' investment and leverage choices', Contemporary Accounting Research 36(1), 513-546. https://doi.org/10.1111/ 1911-3846.12387

Saunders, M., Lewis, P. \& Thornhill, A., 2016, Research methods for business students, 7th edn., Pearson Education Limited, Harlow.

Securities and Exchange Commission (SEC), 2003, Final rule: Conditions for use of nonGAAP financial measures, viewed 05 June 2017, from https://www.sec.gov/rules/ final/33-8176.htm

Securities and Exchange Commission (SEC), 2018, SEC.gov - Compliance and disclosure interpretations: Non-GAAP financial measures, viewed 22 June 2018, from https://www.sec.gov/divisions/corpfin/guidance/nongaapinterp.htm.

Tharisa PIc, 2016, SENS report - Tharisa 2016 consolidated annual results, IRESS Expert, Johannesburg.

Verriest, A., Bouwens, J. \& De Kok, T., 2019, 'The prevalence and validity of EBITDA as a performance measure', Comptabilité-Contrôle-Audit 25(1), 55-105. https://doi. org/10.3917/cca.251.0055

Walton, P.J., 2000, Financial statement analysis: An international perspective, Business Press, London.

White, G.I., Sondhi, A.C. \& Fried, D., 2003, The analysis and use of financial statements, 3rd edn., Wiley, Hoboken, NJ.

Young, S., 2014, 'The drivers, consequences and policy implications of non-GAAP earnings reporting', Accounting and Business Research 44(4), 444-465. https:// doi.org/10.1080/00014788.2014.900952 